ETTE, Ottmar. WeltFraktale: Wege durch die Literaturen der Welt. J.B. Metzler, Sttutgart, 2017. 392p.

\title{
A CAMINHO DE UMA FILOLOGIA DAS LITERATURAS DO MUNDO: RESENHA DA OBRA WELTFRAKTALE
}

\author{
Carla Luciane Klos Schöninger ${ }^{1}$
}

Wie in der Philo-Logie die Liebe zu den Worten, in denen ihre je unterschiedlichen Orte der Hervorbringung mitklingen, stets die Liebe zum Leben in seinen verschiedenartigsten Erscheinungsformen vorausgesetzt ist.

(Ottmar Ette, 2017,p.27)

Nos pensamentos de Erich Auerbach as conexões entre a vida, a leitura e o ato da escrita convertem-se em um método filológico de investigação enfatizado por Ette como um liame de trocas entre textos- analogicamente associado a uma relação aquipélaga, o que evidencia as múltiplas lógicas no método de análise literária. É com Auerbach que Ottmar Ette introduz o percurso a caminho de uma filologia das Literaturas do mundo em sua obra WeltFraktale: Wege durch die Literaturen der Welt [Fractais do mundo: caminhos através das Literaturas do mundo].

Ottmar Ette é professor de Literatura Comparada e Literaturas Românicas na Universidade de Potsdam, Brandemburgo. No ano de 2014 foi eleito membro honorário da Associação Americana de Língua Moderna, desde 2013 é membro da Academia de Ciências e Humanidades de Berlim-Brandemburgo. É membro da Academia Europaea desde 2010 e no mesmo ano tornou-se membro honorário do Instituto de Pesquisa em Línguas Modernas da Escola de Estudos Avançados da Universidade de Londres.

O professor, filólogo e teórico é reconhecido mundialmente pela pesquisa e escrita referentes às teorias literárias, à dinamicidade e movimento no campo literário e às ponderações sobre as múltiplas lógicas na investigação literária. Seus conceitos têm sido alicerce para pesquisadores e acadêmicos das diferentes áreas de conhecimento, principalmente dos estudos comparados. Dentre as principais temáticas por ele trabalhadas, elevam-se as abordagens acerca

\footnotetext{
${ }^{1}$ Doutoranda no PPG em Letras da UFRGS e na Universität Potsdam. Docente do Instituto Federal Farroupilha (IFFAR), campus Panambi/RS.
} 
da Literatura do mundo, estudos de Transárea, convivência, a poética do movimento, estudos literários como ciência da vida e pesquisas acerca de Alexander von Humboldt.

As obras publicadas retomam estudos teóricos, autores e obras clássicas, bem como textos e autores não muito conhecidos em determinadas épocas. Em seus escritos valoriza a transculturalidade, o pensamento nômade, as multiperspectivas, conexões entre continentes e ilhas, pensando na vetorização de paisagens, na ciência em movimento e nas relações de vivências, sobrevivência e convivência entre os diferentes seres- que a literatura é capaz de abordar de maneira tão intensa. Cito Literatur in Bewegung [Literatura em movimento] (2001), Weltbewusstsein. Alexander von Humboldt und das unvollendete Projekt einer anderen Moderne [Consciência mundial. Alexander von Humboldt e o projeto inacabado da outra modernidade] (2002), ÜberLebenswissen. Die Aufgabe der Philologie [SaberSobreViver: A (o)missão da filologia] (2004), ZwischenWeltenSchreiben. Literaturen ohne festen Wohnsitz [EscreverEntre Mundos: Literaturas sem morada fixa] (2005), Konvivenz. Literatur und Leben nach dem Paradies [Convivência. Literatura e vida após o paraíso] (2012), TransArea. Eine literarische Globalisierungsgeschichte [Transárea. Uma história literária da globalização] (2012). Sua produção é ampla e difundida nos diferentes continentes, já que conta com publicações em alemão e traduções para inglês, português, espanhol e francês.

WeltFraktale: Wege durch die Literaturen der Welt foi publicado no ano de $2017 \mathrm{e}$ está estruturado em cinco capítulos: Theorie -Auf dem Weg zu einer Philologie der Literaturen der Welt [Teoria- a caminho de uma filologia das Literaturas do mundo]; Vektoren-Politische und kritische Potentiale relationaler Philologie [Vetores- potenciais políticos e críticos da filologia relacional]; Arquipel I- Occidentes-Orientes [Arquipélago I- Ocidente- Oriente]; ZeitRäume-Vom Lebenswissen der Literaturen der Welt [Horizontes temporais- A partir do conhecimento das Literaturas do mundo] e Archipel II- America(s) transareal [Arquipélago IITransárea na(s) América(s)]. Nos diferentes capítulos, Ette traça linhas que partem de uma abordagem dos métodos dos estudos filológicos e da comparação entre os conceitos: Literatura universal e Literaturas do mundo. O conceito Literaturas do mundo contrasta com o conceito histórico de Goethe (Weltliteratur), sendo algo novo, pois abrange diferentes lógicas de escrita e de interpretação.

No segundo capítulo, Ette traz os movimentos vetoriais nas questões políticas, da natureza e da cultura como importantes potenciais no entendimento filológico e nas relações entre Europa e o "Novo Mundo", entre o ver, o escrever e o viajar (conhecimento nômade). Na sequência, apresenta cartografias do oriente e ocidente, (fazendo uso do termo arquipélago), 
nesse, aborda o conceito de transárea e a ideia do mar mediterrâneo como lugar de mobilidade e trânsito literário e cultural. A literatura como mantimento, a inquietude como movimento e a lírica como movimento compacto são abordadas como conhecimentos da vida nas Literaturas do mundo. No último capítulo o teórico retoma as relações transarquiélagas, reforça os estudos de transárea na(s) America(s) e enfatiza a modernidade e a pós-modernidade na convivência e na poética. A obra é finalizada com referência à arte da antiguidade como representação das fases da Globalização entre os diferentes continentes. Biombos e arte Namban carregam a simbologia do fractal, em que cada parte compõe uma totalidade, bem como elevam as relações transculturais e transareais representadas em seus desenhos e leques.

Sendo assim, neste volume Ottmar Ette retoma textos literários, escritores, filósofos, ensaístas e teóricos que em diferentes épocas percorreram continentes e ilhas, seja na realidade ou na imaginação, ilustrando através da escrita os movimentos de transárea. O conceito de Fraktal abordado por Ette, parte dos estudos de Lévi-Strauss sobre modèle réduit (modelo reduzido), na ideia de que em benefício da representação artística e literária se deve abrir mão das dimensões do modelo; do conceito Mise en abyme (narrativa em abismo), de André Gideno estudo de narrativas que contêm outras narrativas dentro de si e por fim, do conceito "fractal”, do matemático Benoît Mandelbrot, do latim Fractus, significa fração, quebrado. O fractal é uma figura complexa da geometria e é muito encontrado na natureza. Como os fractais são autossimilares e de escala, suas partes separadas repetem os traços do todo completo.

Detentor de uma linguagem rebuscada e instigante, o teórico compôs um texto configurado em constelações de pensamentos, abordagens teóricas e exemplos que dão suporte ao seu conceito literário-filosófico. A obra é indicada a estudiosos de diferentes áreas de conhecimento, por trazer modelos e teorias científicas, filosóficas e sociais, mas principalmente para acadêmicos e pesquisadores do campo literário e artístico, já que aprofunda a abordagem teórica em textos literários.

Em WeltFraktale: Wege durch die Literaturen der Welt, Ottmar Ette ilustra os estudos filológicos pelas múltiplas perspectivas e lógicas, considerando movimentos de transárea nas Literaturas do mundo. Os textos citados e analisados nesse volume passam a ser investigados em pensamentos arquipélagos complexos, que têm na obra de arte, na lírica e na prosa, exemplos do conceito fractal, evidenciando que "nesse fractal do mundo se representa um mundo inteiro" (ETTE, 2019). 


\section{REFERÊNCIAS}

ETTE, Ottmar. WeltFraktale: Wege durch die Literaturen der Welt. J.B. Metzler, Sttutgart, 2017. 392p.

Transarea: a literary history of globalization. Trad. Mark W. Person. Berlin: De Gruyter, 2016.

NEUMANN, G. R.; SCHÖNINGER, C.L.K. Entrevista com Ottmar Ette. Alea: estudos neolatinos, v.21, n.3, p. 229-237, 2019. Disponível em: <https://doi.org/10.1590/1517$\underline{106 x / 2019213229237>}$

Recebido em 23/9/2020.

Aceito em 18/11/2020. 